\title{
Bacteria Associated with Arbuscula Mycorrhizal Spores Gigaspora margarita and Their Potential for Stimulating Root Mycorrhizal Colonization and Neem (Melia azedarach Linn) Seedling Growth
}

\author{
SRI WILARSO BUDI ${ }^{1}$, YENNI BAKHTIAR ${ }^{2}$, AND NUNANG LAMAEK MAY ${ }^{3}$ \\ ${ }^{\prime}$ Department of Silviculture Faculty of Forestry, Institut Pertanian Bogor, Campus IPB Darmaga. Bogor 16680, Indonesia; \\ ${ }^{2}$ Center of Biotechnology, Badan Pengkajian dan Penerapan Teknologi, Gedung 630 Kawasan Puspitek Serpong \\ Tangerang Selatan 15314, Indonesia; \\ ${ }^{3}$ Faculty of Forestry, Universitas Cendrawasih, Jalan Camp Wolker, Jayapura 99358, Papua, Indonesia
}

Four isolates (BGi1, BGi2, BGi3, and BGi4) bacteria were isolated from surface sterilized arbuscular mycorrhizal fungi (AMF) spores of Gigaspora margarita $(\mathrm{Gm})$. Based on 16S rDNA analyses and phylogenetic tree, it was revealed that isolates BGi1, BGi3 and BGi4 belong to genus Bacillus, whereas BGi2 was very close to Bacillus megaterium EG 24. Enzymatic activity test showed that all four isolates had cellulase and protease activities; while one isolate (Bacillus sp. BGi4) also has pectinase activity in addition to the celulase and protease activities. Dual inoculation of Melia azedarch Linn roots by B. megaterium BGi2 and AMF spores G. margarita enhanced mycorrhizal root colonization by $58.3 \%$. Combination of Bacillus sp. BGil and G. margarita increased height, diameter, shoot biomass, and root biomass of M. azedarch by $353,4.8,4546$, and $2810 \%$, respectively, in comparison to the uninoculated control plant.

Key words: bacteria, arbuscular mycorrizal fungi, stimulation effects, root colonization, plant growth

Empat isolat bakteri (BGi1, BGi2, BGi3, dan BGi4) telah diisolasi dari spora fungi mikoriza arbuscula Gigaspora margarita $(\mathrm{Gm})$ yang dsterilisasi permukaannya. Berdasarkan pada analisis urutan gen 16S rDNA dan pohon filogenetik, keempat isolat tersebut termasuk ke dalam genus Bacillus sedangkan isolat BGi2 mempunyai kemiripan tinggi dengan Bacillus megaterium EG 24. Uji enzimatik menunjukkan bahwa keempat isolat menghasilkan enzim selulase dan protease. Satu isolat Bacillus sp. BGi4 menghasilkan enzim selulase, protease, dan pectinase. Inokulasi tanaman Melia azedarch Linn dengan B. megaterium BGi2 dan spora $G$. margarita meningkatkan kolonisasi akar sebesar 58,3\%. Kombinasi Bacillus sp. BGil dan G. margarita meningkatkan pertumbuhan tinggi, diameter, biomass pucuk, dan biomass akar M. azedarch berturut-turut 353 $\%, 4,8 \%, 4546 \%$, dan $2810 \%$, dibanding tanaman kontrol.

Kata kunci: bakteri, fungi mikoriza arbuskula, pengaruh rangsangan, kolonisasi akar, pertumbuhan tanaman

Arbuscular mycorrhizal fungi (AMF) is one of the soil microorganisms composing the essential components of sustainable soil-plant system. These fungi provide numerous benefits to their host, including better phosphorus uptake (Gossous and Mohammad 2009), increased absorption of nitrogen (Rotor and Delima 2010), production of plant growth hormones (Herrera-Medina et al. 2007), defending root against soil borne diseases (Bakhtiar et al. 2010) and increasing plant growth and productivity (Duponnois et al. 2005). Several types of microorganisms were reported to be associated with the rhizospheres of different host plants colonized by arbuscular mycorrhizal fungi (AMF). These microbes were identified as $\mathrm{N}_{2}$-fixing bacteria (Secilia and Bagyaraj 1987), plant growth-promoting rhizobacteria

*Corresponding author; Phone: +62-251-8626806, E-mail: wilarso62@yahoo.com
(Jargeat et al. 2004), phosphate solubilizing bacteria (Cruz and Ishii 2011), and antagonists of plant pathogens (Budi et al. 1999a, Bakhtiar et al. 2010).

The interaction between AMF with different types of mycorrhizosphere bacteria can influence their development and symbiotic establishment. Hildebrandt et al. (2002) reported the increase of AMF fungal growth when combined with bacteria. The AM fungal colonization (Mamatha et al. 2002), inhabitation of plant pathogen fungi (Maier et al. 2004), and agriculture and forestry plant growth (Barea et al. 2002) have been reported to increase by mycorrhizosphere bacteria inoculation.

Recently some bacteria were reported to be associated with AMF like mycelium and surface sterilized spore. The bacterial genus Paenibacillus was intimately associated with the mycelium of AMF Glomus intraradices (Mansfeld-Giese et al. 2002). The bacteria species Janthinobacterium lividum 
(KCIGM01), and Paenibacillus polymixa (KCIGM04) have been reported to be associated with AMF spore of Gigaspora margarita (Cruz et al. 2008). Cruz and Ishii (2011) reported that some bacteria Bacillus sp (KTCIGM01), Bacillus thuringiensis (KTCIGM02), and Paenibacillus rhizospherae (KTCIGM03) have been isolated from surface sterilized AMF spore of Gigaspora magrarita. The bacteria associated with AMF spore of Glomus geosporum and Glomus constrictum have been reported by Roesti et al. (2005). The fact that bacteria isolated from surface sterilized AMF spores can increase phosphate solubilisation and suppression of pathogenic fungi had been reported by Cruz et al. (2008). However, no data on the effects of associated bacteria isolated from surface sterilized AMF spore on the growth of forest trees are available.

The Neem, Melia azedarach Linn. (Meliaceae) are native trees of Asia, including Indonesia (Orwa et al. 2009) and widely planted in West Java as a community forest tree (Yulianti et al. 2011). Neem tree is one of the potential forest trees species for reforestation and medicinal plants (Selvaraj and Mosses 2011). This plant has a fairly coarse root system with very few root hairs, which are common characteristics of plants that are very responsive to arbuscular mycorrhizal symbiosis. The objectives of the present study were to isolate and identify bacteria from surface sterilized spores of AMF G. margarita and their effects on mycorrhization and growth of Neem seedling.

\section{MATERIALS AND METHODS}

\section{Isolation of Bacteria from the Arbuscular} Mycorrhizal Spores. The spores of AMF $G$. margarita originated from the collection of Silviculture Laboratory, Faculty of Forestry, Institut Pertanian Bogor (IPB) were sieved by wet sieving according to the method of Gardeman and Nicholson (1963). Fifty spores were then surface sterilized by the method prescribed by Budi et al. (1999b). The surfaced sterilized spores were then placed in petri dishes containing sterile Pseudomonas Agar and Nutrient Agar and then incubated in the dark at $30{ }^{\circ} \mathrm{C}$. The bacteria were then isolated and purified. Each single colony was then transferred to agar slants and stored at $4{ }^{\circ} \mathrm{Cuntil}$ used.

Identification of Bacterial Isolates. Isolates of bacteria were identified following the method described by Budi et al. (1999a) and Bakhtiar et al. (2010), by sequence analysis of the small ribosomal subunit (16S ribosomal DNA) after PCR amplification with eurobacterial primers
765 R (5'-CTGTTTGCTCCCCACGTTTC-3') and 1141 R (5'-GCCTTGCGCTCGTTGC-3') from Alpha DNA Canada (Bakhtiar et al. 2010). The DNA contigs were assembled using ATGC program that connects the $765 \mathrm{R}$ and $1141 \mathrm{R}$ primers. The sequences were compared with DNA sequences available in GenBank database of NCBI using BLAST programme. Alignment of $16 \mathrm{~S}$ rDNA sequences were performed using ClustalX. The phylogenetic tree was constructed by comparing $16 \mathrm{~S}$ rDNA sequences of four isolated bacteria with 16S rDNA sequences from GeneBank DNA database and then visualized using Tree View 1.6.6.

Test of Enzymatic Activity of Bacteria in Vitro. The characterization of cellulalitic and pectinolytic activity was carried out according to the method of Teather and Wood (1982) whereas the proteolitic activity was characterized according to the method described by Dunne et al. (1997). The experiment was performed in a completely randomized design in petri dishes in triplicates.

Dual Inoculations of Bacteria and Arbuscular Mycorrhizal Spores on M. azedarach. The experiments were performed by factorial design with two different treatments of arbuscular mycorrhizal inoculations (inoculated and uninoculated), and five different types of isolate used as inoculums (uninoculated, and inoculated with isolate BGi1, Bgi2, BGi3, and BGi4). The experiment was arranged in a completely randomized design in a polybag culture in five replicates. Three week old $M$. azedarach seedlings with four leaves were transplanted into $500 \mathrm{~mL}$ polybags containing sterilized ultisol soil. The properties of soil medium were determined following the standard method used in Soil Laboratory, IPB. The soil medium was very low in phosphorus and other nutrients but had high aluminium concentration (Table 1). The plant was either inoculated with surface sterilized AMF spores G. margarita and bacterial isolates or not inoculated, as a control at transplanting. Each inoculated plant received 50 surface sterilized AMF spores and $5 \mathrm{~mL}$ bacteria solution containing $10^{8}$ colony forming unit (CFU) $\mathrm{mL}^{-1}$ of bacteria placed near the roots plant. Plants were grown for twelve weeks in the green house and watered as needed. Plants were harvested twelve weeks after transplanting and evaluated for height, diameters shoot, and root dry weight. AMF root colonizations were evaluated after being cleaned with $2.5 \% \mathrm{KOH}$, and stained with 0.05 $\%$ trypan blue in acidic glycerol (Koske and Gemma 1989). Percent AMF roots colonizations were determined according the method of Biermann and 
Linderman (1981). All data were analyzed by Analysis of Variance Procedure using SPSS software program.

\section{RESULTS}

Isolation of Spore Associated Bacteria. A total of four bacterial isolates were isolated and purified from surface sterilized spores of AMF G. margarita. The morphological characteristic of each isolate bacterium such as color, shape, and colonies were used for separating the isolates. The bacterial isolates showed different morphological characteristic (Table 2).

Identification of Bacterial Isolates. Bacterial isolates were identified based on their 16S rDNA analyses (Table 2). Phylogenetic analyses of 16S rDNA showed correlation with 18 strains cited from GenBank and all isolates belonged to the genera Bacillus spp. (Fig1).

Test of Enzymatic Activity of Bacteria in vitro. Enzymatic test activity showed that bacterial isolates Bacillus sp. BGi1, Bacillus megaterium BGi2, Bacillus sp. BGi3, and Bacillus sp. BGi4 produced zones of hydrolysis on Carboxyl Methyl Cellulose (CMC) and protein medium. In addition, the bacterial isolate Bacillus sp. BGi4 also produced zone of hydrolysis on pectine media tested as indicated by clear zones (halo) around the colonies (Table 4). The medium containing pectin was weakly degraded (1 mm zone surrounding

Table 1 Chemical properties of growing media used in this experiment

\begin{tabular}{|c|c|c|c|}
\hline $\mathrm{pH} \mathrm{H} \mathrm{H}_{2} \mathrm{O}$ & 4.5 & $\mathrm{Na}(\mathrm{me} / 100$ gram $)$ & 0.13 \\
\hline $\mathrm{pH} \mathrm{HCl}$ & 3.7 & CEC (me/100 gram) & 23.38 \\
\hline C-organic (Walkley \& Black) \% & 2.64 & Base saturation $(\%)$ & 4.49 \\
\hline N-Total (Kjeldhal) \% & 0.24 & Al-dd (me/100 gram) & 1132 \\
\hline $\mathrm{C} / \mathrm{N}$ & 11 & H-dd (me/100 gram) & 0.51 \\
\hline P (Bray I) ppm & 8.6 & $\mathrm{Fe}$ (me/100 gram) & 4.08 \\
\hline $\mathrm{P}(\mathrm{HCl} 25 \%) \mathrm{ppm}$ & 206.6 & $\mathrm{Cu}(\mathrm{me} / 100$ gram $)$ & 0.08 \\
\hline $\mathrm{Ca}(\mathrm{me} / 100$ gram $)$ & 0.47 & Zn (me/100 gram) & 0.68 \\
\hline $\mathrm{Mg}(\mathrm{me} / 100$ gram $)$ & 0.28 & Mn (me/100 gram) & 7.56 \\
\hline $\mathrm{K}$ (me/100 gram) & 0.17 & & \\
\hline
\end{tabular}

Table 2 Species identification and characteristic morphology of isolates of bacteria isolated from arbuscula mycorrhizal spores of Gigaspora margarita

\begin{tabular}{lllll}
\hline $\begin{array}{c}\text { No. } \\
\text { Code }\end{array}$ & $\begin{array}{c}\text { Isolats } \\
\text { colony (colour, colony surface } \\
\text { and shape) }\end{array}$ & \multicolumn{1}{c}{$\begin{array}{c}\text { Morphological characteristic of } \\
\text { (Irregular, lobate, raised, opaque. }\end{array}$} & $\begin{array}{c}\text { Species name with } \\
\text { the highest } \\
\text { identity (\%) }\end{array}$ \\
\hline 1 & BGi1 & Positive & Bacillus sp. BD-107 (99\%) \\
2 & BGi2 & $\begin{array}{l}\text { Circular, entiere, convex, glossy, } \\
\text { brown cream, oaque }\end{array}$ & Positive & $\begin{array}{l}\text { Bacillus megaterium } \\
\text { EG 24 (100\%) }\end{array}$ \\
3 & BGi3 & $\begin{array}{l}\text { Circular, undulate, pulvinate, } \\
\text { opaque }\end{array}$ & Positive & $\begin{array}{l}\text { Bacillus subtilis } \\
\text { DF 61 (100\%) }\end{array}$ \\
4 & BGi4 & Irregular, undulate, cream, opaque & Positive & $\begin{array}{l}\text { Bacillus flexus strain } \\
\text { KSC_SF9c (100\%) }\end{array}$ \\
\hline
\end{tabular}


the colony), whereas the media containing $\mathrm{CMC}$ and protein were very strongly degraded ( $>2 \mathrm{~mm}$ zone surrounding the colony).

Effect of Bacteria and Arbuscular Mycorrhizal Fungi on Root Colonization and Plant Growth. After 12 weeks inoculation, significantly higher AMF roots colonization was found in plants inoculated by bacterial isolate $B$. megaterium BGi2.There was an increase by $58.3 \%$ in comparison to plants inoculated with arbuscular mycorrhiza alone (Table 3). On the other hand, plants inoculated with bacterial isolates Bacillus sp. BGi1, Bacillus sp. BGi3, and Bacillus sp. BGi4 only had the AMF roots mycorrhization increased by 10,55 , and $0 \%$, respectively.

AMF inoculation significantly increased height, diameter, shoot and root dry weights of Neem seedling (Table 5). No significantly different effects were observed on any growth parameters when different bacterial isolates were applied on their own. All isolates tended to increase all growth parameters of Neem seedling (Table 5). Dual inoculation of AMF and bacteria significantly increased growth and development of Neem seedlings in comparison to uninoculated plants. Inoculation with AMF alone gave the best growth and increased the height, diameter, shoot and root dry weights by $399,5.4,5304$, and 4038 $\%$, respectively. Dual inoculation with AMF and bacterial isolates produced lower results on all growth parameter than single inoculation with AMF alone. However, these results were not significantly different

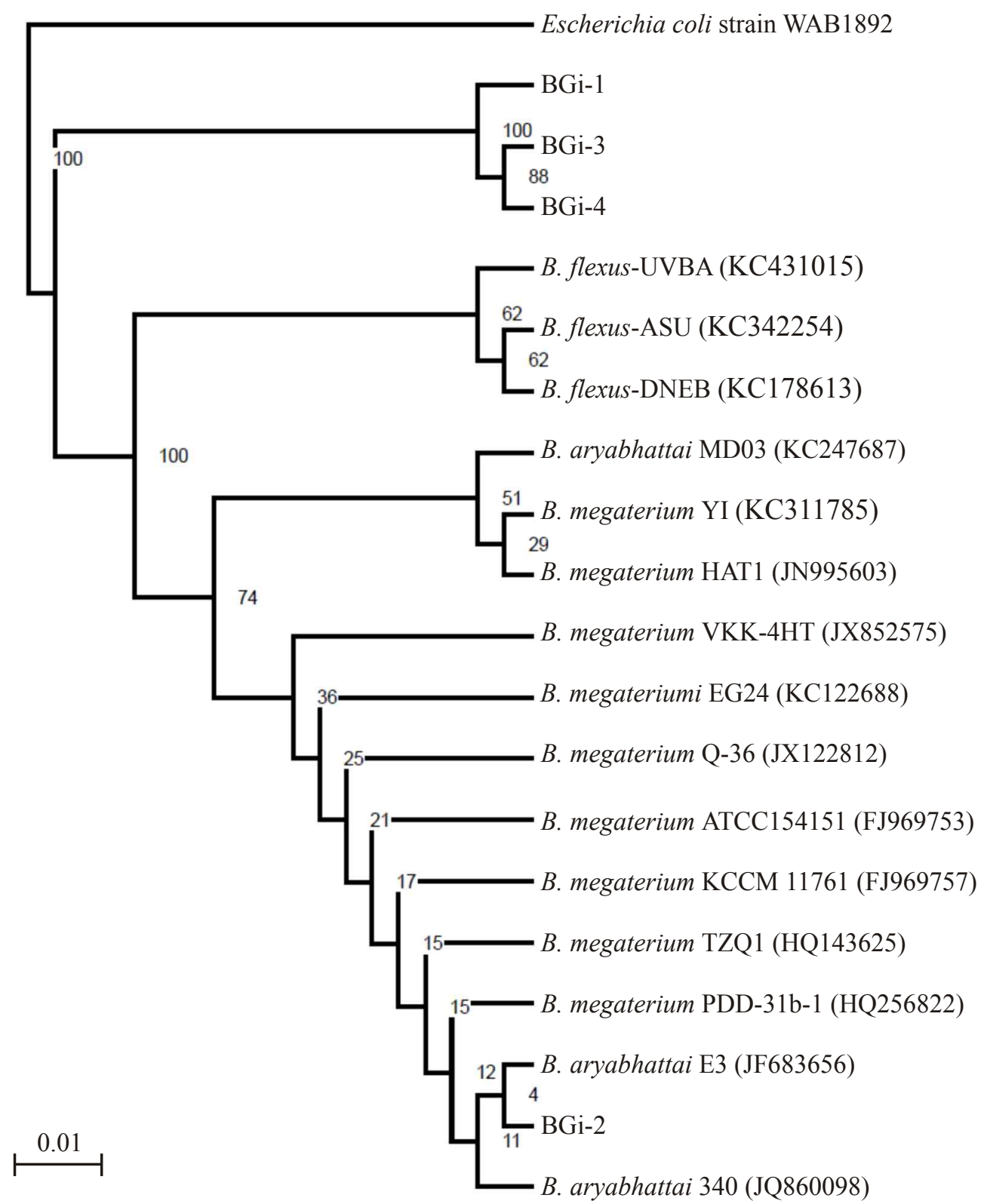

Fig 1 Phylogenetic tree of bacteria isolates from surface sterilized AMF spores Gigaspora margarita. GenBank accession numbers are given after the strain name. Bar, 1 substitution per 100 nucleotides. 
on combination using bacterias isolates Bacillus sp. BGi1, and B. megaterium BGi2. On the other hand, dual inoculation of AMF and Bacillus sp. BGi1 increased the height, diameter, shoot and root dry weights of Neem seedlings by $353,4.9,4512$, and $2752 \%$, respectively. The values were increased by $335 \%, 4.5,3700$, and $1847 \%$, respectively, when inoculation was performed in combination with B. megaterium BGi2.

When plants were inoculated with bacterial isolates alone, their growth and development tended to increase in comparison to the uninoculated plants (Table 5). The height was increased by $17,11.1,21.6$, and $14.1 \%$ when inoculated with Bacillus sp. BGi1, Bacillus megaterium BGi2, and Bacillus sp. BGi3, and Bacillus sp. BGi4, respectively. had been detected in several member of the Gigasporaceae. Bianciotto et al. (2004) found intracellular bacteria in all fungal life cycle; spores, germ tube, extra, and intraradical hyphae, except arbuscula of Gigaspora rosea. An average of about 20000 bacteria in one spore of G. margarita had been detected (Bianciotto et al. 2003), and identified as a new taxon termed Candidatus Glomeribacter gigasporarum (Jargeat et al. 2004). Recently Cruz et al. (2008) and Cruz and Ishii (2011) found three genera of bacteria Jantibacterium, Bacillus, and Paenibacillus from surface sterilized spores $G$. margarita. This research revealed that G. margarita, originally from tropical region, also harbored other bacteria in addition to those already reported. The

Table 3 Clear zone $(\mathrm{mm})$ of Celluase, protease and pectinase activity produced by bacterial isolat after $3 \mathrm{~d}$ incubation

\begin{tabular}{clccc}
\hline No & \multicolumn{1}{c}{ Strain's name } & Cellulase & Protease & Pectinase \\
\hline 1 & Bacillus sp. BGi1 & $4.8 \mathrm{a}$ & $6.6 \mathrm{a}$ & $0.0 \mathrm{~b}$ \\
2 & Bacillus megaterium BGi2 & $2.0 \mathrm{~b}$ & $3.0 \mathrm{c}$ & $0.0 \mathrm{~b}$ \\
3 & Bacillus sp. BGi3 & $5.1 \mathrm{a}$ & $5.2 \mathrm{~b}$ & $0.0 \mathrm{~b}$ \\
4 & Bacillus sp. BGi4 & $5.0 \mathrm{a}$ & $6.7 \mathrm{a}$ & $1.0 \mathrm{a}$ \\
\hline
\end{tabular}

*Values in a column followed by the same letter do not differ significantly from each other

Table 4 Effect of bacterial isolates on AMF roots colonization of Melia azedarach 12 weeks after inoculation

\begin{tabular}{clc}
\hline Mycorrhizae & \multicolumn{1}{c}{ Strains's name } & Roots colonization (\%) \\
\hline No & Bacillus sp. BGi1 & 0.00 \\
& Bacillus megaterium BGi2 & 0.00 \\
& Bacillus sp. BGi3 & 0.00 \\
Yes & Bacillus sp. BGi4 & 0.00 \\
& Uninoculated & $40.00^{\mathrm{b}}$ \\
& Bacillus sp. BGi1 & $44.00^{\mathrm{b}}$ \\
& Bacillus megaterium BGi2 & $63.33^{\mathrm{a}}$ \\
& Bacillus sp. BGi3 & $62.00^{\mathrm{a}}$ \\
& Bacillus sp. BGi4 & $39.33^{\mathrm{b}}$ \\
\hline
\end{tabular}

*Values in a column followed by the same letter do not differ significantly from each other

\section{DISCUSSION}

The present study showed that surface sterilized AMF spores of $G$. margarita, a member of Gigasporaceae, harbor several different bacterial strains. Based on phylogenetic correlation analyses, all isolated bacteria belong to Bacillus sp. genera. Previous research showed that endosymbiotic bacteria morphological features of the bacteria including shape, and color confirmed the information provided by other researchers.

Based on the bacterial isolates' enzymatic activity tests, it was shown that all bacterial isolates produced different amount hydrolytic enzyme activities as indicated by clear zone (Table 3 ). It was demonstrated that the hydrolytic enzyme played important roles in 
Table 5 Effect of bacteria and AMF on growth and development of Melia azedarach seedling 12 weeks after inoculation

\begin{tabular}{clcccc}
\hline Mycorrhizae & \multicolumn{1}{c}{ Strain's name } & Height (cm) & Diameter (cm) & $\begin{array}{c}\text { Shoot dry } \\
\text { weight (g) }\end{array}$ & $\begin{array}{c}\text { Root dry } \\
\text { weight (g) }\end{array}$ \\
\hline No & No bacteria & $3.98^{\mathrm{c}}$ & $0.909^{\mathrm{d}}$ & $0.026^{\mathrm{c}}$ & $0.021^{\mathrm{d}}$ \\
& Bacillus sp. BGi1 & $4.66^{\mathrm{c}}$ & $0.911^{\mathrm{cd}}$ & $0.037^{\mathrm{c}}$ & $0.025^{\mathrm{d}}$ \\
& Bacillus megaterium BGi2 & $4.42^{\mathrm{c}}$ & $0.912^{\mathrm{cd}}$ & $0.031^{\mathrm{c}}$ & $0.026^{\mathrm{d}}$ \\
& Bacillus sp. BGi3 & $4.84^{\mathrm{c}}$ & $0.918^{\mathrm{cd}}$ & $0.039^{\mathrm{c}}$ & $0.033^{\mathrm{d}}$ \\
& Bacillus sp. BGi4 & $4.54^{\mathrm{c}}$ & $0.911^{\mathrm{cd}}$ & $0.031^{\mathrm{c}}$ & $0.027^{\mathrm{d}}$ \\
Yes & $19.86^{\mathrm{a}}$ & $0.958^{\mathrm{a}}$ & $1.405^{\mathrm{a}}$ & $0.869^{\mathrm{a}}$ \\
& No bacteria & $18.02^{\mathrm{a}}$ & $0.953^{\mathrm{a}}$ & $1.199^{\mathrm{ab}}$ & $0.599^{\mathrm{ab}}$ \\
& Bacillus sp. BGi1 & $17.30^{\mathrm{ab}}$ & $0.952^{\mathrm{a}}$ & $0.988^{\mathrm{ab}}$ & $0.409^{\mathrm{bc}}$ \\
& Bacillus megaterium BGi2 & $13.88^{\mathrm{b}}$ & $0.942^{\mathrm{b}}$ & $0.706^{\mathrm{c}}$ & $0.395^{\mathrm{c}}$ \\
& Bacillus sp. BGi3 & $7.86^{\mathrm{c}}$ & $0.923^{\mathrm{c}}$ & $0.374^{\mathrm{c}}$ & $0.143^{\mathrm{d}}$ \\
\hline
\end{tabular}

*Values in a column followed by the same letter do not differ significantly from each other

facilitating hyphae to enter the epidermis roots in small amount (Bonfante and Perotto 1995). In this research, as shown in Table 3, three bacterial isolates produced cellulolytic and proteolytic activities, while one isolate produced cellulolytic, proteolytic and pectinolytic activities at different amounts as indicated by the width of the clear zones. The bacterial isolate $B$. megaterium BGi2 produced cellulase and protease in smaller amount compared to other bacterial isolates and had greater mycorrhizal root colonization compared to other bacterial isolates (Table 4). The present studies showed that bacteria isolated from surface sterilized AMF spores of G. margarita produced hydrolytic enzymes and played important roles on facilitating AMF symbiosis development on neem seedling. As shown in Table 4, the degree of mycorrhizal root colonization also depended on the amount of enzymes produced. The enhancement of AMF root colonization in the presence of non-spore-associated bacteria had been reported previously by other researchers (Artursson 2005; Duponnois and Plenchette 2003) and we assume that those bacteria also produce hydrolytic enzyme activity.

Arbuscular mycorrhizal fungi are obligate symbionts that establish symbioses with plants in order to obtain carbon, enabling them to grow and complete their life cycle (Harrison 2005). In turn, the fungus will assist the plant with the acquisition of mineral nutrient, in particular phosphorous. According to Smith et al. (2003) in AM symbiosis, plants receive all of their phosphorous via their fungal symbiosis, in consequence the symbiosis establishment is very critical and hydrolytic enzyme could facilitate hyphae of AMF enter to the root.

The role of the bacteria in the growth and development of arbuscular mycorrhizal fungi had been well documented (Frey-Klett and Garbaye 2005). They play roles in promoting the establishment of symbiosis, stimulating mycelia extension, increasing root-fungus contacts and colonization and reducing the impact of adverse environmental condition on the mycelium of the mycorrhizal fungi. Different mechanisms of bacterial effects on mycorrhizal development had been reported by several researchers. Keller et al. (2006) found that secondary metabolites responsible for growth promotion of arbuscula mycorrhizal fungi were produced by bacteria. The production of hydrolytic enzymes by mycorrhizosphere bacteria that caused cell wall degradation of pathogenic fungi had been reported (Budi et al. 2000).

The evidence that arbuscular mycorrhizal fungi might enhance plant growth and development was well documented (Johansson et al. 2004). This research demonstrated that Neem seedling grown in unfertile soil (Table 1) and inoculated by arbuscular mycoorhizal fungi $G$. margarita significantly 
increased their height, diameter and shoot and root biomass growth in comparison to uninoculated control (Table 5). Increasing growth and development of Azadirachta indica A. Juss, a forest tree of the same family with $M$. azedarchta, inoculated by arbuscular mycorrhizal fungi, had been reported (Phavaphutanon et al. 1996). The present study is in accordance with the above findings, showing that $M$. azedarach grown in unfertile soil and inoculated with arbuscular mycorrhiza increased their growth. Phosphorous is one of the mineral nutrients essential for plant growth and development (Shtark et al. 2010), although in this research the phosphorous absorption was not evaluated, it was demonstrated that AM fungi improve phosphorous uptake from soils in particularly in soil with low P availability (Olsson et al. 2006).

Although bacterial isolates enhanced plant growth and development, co-inoculation with arbuscular mycorrhizal fungi decreased their growth in comparison to plants inoculated with arbuscular mycorrhizal alone (Table 5). This was probably due to the neem seedling was still in the early growth stage and the nutritional contribution from bacteria and arbuscular mycorrhizae was limited. Correa et al. (2006) reported that ectomycorrhiza formation may have a detrimental rather than a beneficial effect on plant productivity during their establishment and early development stage. The effect depends on the amount of $\mathrm{N}$ available to the plant, on the nutritional status and on the age of the plant. The interaction between arbuscular mycorrhizal fungi and bacteria could positively enhance mycorrhizal development and function and plant growth (Hameeda et al. 2007). Other researcher found a negative effect by reduced spore germination and hyphae length, decreased root colonization, and a decline in the metabolic activity of the internal mycelium (Gryndler et al. 1996) or no effect to mycorrhizal development (Edwards et al. 1998). In this research three bacterial isolates i.e. Bacillus sp. BGi1, B. megaterium BGi2, and Bacillus sp. BGi3 positively enhance mycorrhizal root colonization and one isolate Bacillus sp. BGi4 showed a neutral effect. It was reported that Bacillus subtilis isolated from oil palm mycorrhizosphere can be used as biocontrol agent of Ganoderma (Bakhtiar et al. 2010). Furthermore, it is necessary to investigate the possible combination of AMF and Bacillus sp. BGi3 most related to $B$. subtilis towards against Ganoderma fungi.

Based on the findings of this study, it can be concluded that bacterial isolates Bacillus sp. BGi1, $B$. megaterium BGi2 and Bacillus sp. BGi3 isolated from surface sterilized AMF spores G. margarita are potential for enhancing AMF root colonization on neem seedling. All bacterial isolates enhanced neem seedling growth, but when combinations of AMF and bacterial isolates were applied, it tended to decrease early growth of neem seedlings in the nursery.

\section{ACKNOWLEDGMENTS}

The authors wish to thank to Prijanto Pamungkas, Head of Silviculture Laboratory who gave permission using facilities and chemical reagents for this reasearch. Thank also goes to Josepha for her technical assistant during experiment.

\section{REFERENCES}

Artursson V, Finlay RD, Jansson JK. 2006. Interactions between arbuscular mycorrhizal fungi and bacteria and their potential for stimulating plant growth. Environ Microbiol. 8(1):1-10. doi:10.1111/j.14622920.2005.00942.x.

Bakhtiar Y, Yahya S, Sumaryono W, Sinaga MS, Budi SW, and Tajudin T. 2010. Isolation and Identification of Mycorrhizosphere Bacteria and Their Antagonistic Effects Towards Ganoderma boniense in vitro. Microbiol Indones. 4 (2) : 96-102.

Barea JM, Azcon R, Azcon-Aguilar C. 2002. Mycorrhizosphere interactions to improve plant fitness and soil quality. Antonie Van Leeuwenhoek. 81:343351.doi: 10.1023/A:1020588701325.

Bianciotto V, Lumini E, Bonfante P, Vandamme P. 2003. 'Candidatus Glomeribacter gigasporarum' gen. nov., sp nov., an endosymbiont of arbuscular mycorrhizal fungi. Int J Syst Evol Microb. 53(1): 121-124.

Bianciotto, V, Genre A, Jargeat P, Lumini E, Becard G, Bonfante P. 2004. Vertical transmission of endobacteria in the arbuscular mycorrhizal fungus Gigaspora margarita through generation of vegetative spores. Appl Environ Microbiol. 70(6):3600-3608. doi: 10.1128/AEM.70.6.

Biermann B, Linderman RG. 1981. Quantifying vesicular arbuscular mycorrhizae: A proposes method towards standardization. New Phytol. 87(1): 63-67. doi: 0028$646 \mathrm{x} / 81 / 010063+05 \$ 02.00 / 0$.

Bonfante P, Perotto S. 1995. Strategies of arbuscular mycorrhizal fungi when infecting host plants. New Phytol. 130(1):3-21. doi:10.1111/j.14698137.1995.tb01810.x

Budi SW, van Tuinen D, Martinotti G, Gianinazzi S. 1999a. Isolation from the Sorghum bicolor mycorrhizosphere of a bacterium compatible with arbuscular mycorrhiza development and antagonistic towards soilborne fungal pathogens. Appl Environ Microbiol. 65: 5148-5150. doi: 0099-2240/99/\$04.0010. 
Budi SW, Blal B, Gianinazzi S. 1999b. Surface sterilization of Glomus mosseae sporocarpes for studying endomycorrhization in vitro. Mycorrhiza 8: 15-18.

Budi SW, van Tuinen D, Arnould C,.Dumas-Gaudot E, Gianinazzi-Pearson V, Gianinazzi S. 2000. Hydrolitic enzyme activity of Paenibacillus sp. strain B2 and effects of the antagonistic bacterium on cell integrity of two soil-borne pathogenic fungi. Applied Soil Ecol. 15(2) : 191-199. doi: 10.1016/S0929-1393(00)00095-0.

Correa A, Strasser RJ, Martins-Louc MA. 2006. Are mycorrhiza always beneficial? Plant and Soil. 279(12): 65-73. doi: 10.1007/s11104-005-7460-1.

Cruz AF, Horii S, Ochiai S, Yasuda A, Ishii T. 2008. Isolation and analysis of bacteria associated with spores of Gigaspora margarita. J Appl Microbiol. 104(6):17111717. doi:10.1111/j.1365-2672.2007.03695.x.

Cruz AF, Ishii T. 2011. Arbuscular mycorrhizal fungal spores host bacteria that affect nutrient biodynamics and biocontrol of soilborne plant pathogens. Biology Open 000. doi: 10.1242/bio.2011014, 1-6.

Dunne C, Crowly JJ, Moenne-Loccoz Y, Dowling DN, de Bruijn FJ, O'Gara F.1997. Biological control of Pythium ultinum by Stenotromonas maltophilia W18 is mediated by extra cellular proteolytic activity. Microbiology 143(39) : 21-39.

Duponnois R, Plenchette C. 2003. A mycorrhiza helper bacterium enhances ectomycorrhizal and endomycorrhizal symbiosis of Australian Acacia species. Mycorrhiza. 13(2): 85-91. doi:10.1007/s00572-002-0204-7.

Duponnoisa R, Colombeta A, Hienb V, Thioulouse J. 2005. The mycorrhizal fungus Glomus intraradices and rock phosphate amendment influence plant growth and microbial activity in the rhizosphere of Acacia holosericea. Soil Biol Biochem. 37(8): 1460-1468. doi: 10.1016/j.soilbio.2004.09.016.

Edwards SG, Young JPW, Fitter AH. 1998. Interactions between Pseudomonas fluorescens biocontrol agents and Glomus mosseae, an arbuscular mycorrhizal fungus, within the rhizosphere. FEMS Microbiol Lett. 166: 297303. doi:10.1111/j.1574-6968.1998.tb13904.x.

Frey-Klett P, Garbaye J. 2005. Mycorrhiza helper bacteria: a promising model for the genomic analysis of fungalbacterial interactions. New Phytol. 168(1):4-8. doi: 10.1111/j.1469-8137.2005.01553.x.

Gardemann JW, Nicholson TH. 1963. Spores of mycorrhizal Endogones species extracted from soil by wet-sieving and decanting. Trans Br Mycol Soc. 46: 235-244. doi:10.1016/S0007-1536(63)80079-0.

Goussous SJ, Mohammad MJ. 2009. Comparative effect of two arbuscular mycorrhizae and $\mathrm{N}$ and P Fertilizers on growth and nutrient uptake of onions. Int J Agr Biol. $11: 463-467$.

Gryndler M, Hrselova H, Chvatalova I. 1996. Effect of freesoil-inhabiting or rootassociated microfungi on the development of arbuscular mycorrhizae and on proliferation of intraradical mycorrhizae hyphae. Folia Microbiologica 41(2): 193-196. doi: 10.1007/BF02814 698.
Hameeda B, Srijana M, Rupela OP, Reddy G. 2007. Effect of bacteria isolated from composts and macrofauna on sorghum growth and mycorrhizal colonization. World J Microb Biotech. 23(6): 883-887. doi: 10.1007/s112749301-7.

Harrison MJ. 2005. Signaling in the arbuscular mycorrhizal symbiosis. Annu Rev Microbiol. 59:19-42. doi: 10.1146/annurev.micro.58.030603.123749.

Herrera-Medina MJ, Steinkellner S, Vierheilig H, Bote JAO, Garrido JMG. 2007. Abscisic acid determines arbuscule development and functionality in the tomato arbuscular mycorrhiza. New Phytologist. 175(3): 554564. doi: 10.1111/j.1469-8137.2007.02107.x.

Hildebrandt U, Janetta K, Bothe H. 2002. Towards growth of arbuscular mycorrhizal fungi independent of a plant host. Appl Environ Microbiol. 68(4): 1919-1924. doi:10.1128/AEM.68.4.

Jargeat P, Cosseau C, Ola'h, B, Jauneau A, Bonfante P, Batut J. Bécard G. 2004. Isolation, free-living capacities, and genome structure of 'Candidatus Glomeribacter gigasporarum', the endocellular bacterium of the mycorrhizal fungus Gigaspora margarita. J Bacteriol. 186(20): 6876-6884.

Johansson JF, Paul LR, Finlay, RD. 2004. Microbial interactions in the mycorrhizosphere and their significance for sustainable agriculture. FEMS Microbiol Ecol. 48(1): 1-13. doi: 10.1016/j.femsec.2003.11.012.

Keller S, Schneider K, Sussmuth RD. 2006. Structure elucidation of auxofuran, a metabolite involved in stimulating growth of fly agaric, produced by the mycorrhiza helper bacterium Streptomyces AcH 505. J Antibiot. (Tokyo). 59: 801-803. doi:10.1038/ja.2006.106.

Koske RE, Gemma JN. 1989. A modified procedure for staining roots to detect VA mycorrhizas. Mycor Res. 92(4): 486-505. doi: 10.1016/S0953-7562(89)80195-9.

Maier A, Riedlinger J, Fiedler HP, Hampp R. 2004. Actinomycetales bacteria from a spruce stand: characterization and effects on growth of root symbiotic, and plant parasitic soil fungi in dual culture. Mycol Prog. 3(2): 129-136. doi: 10.1007/s11557-006-0083-y.

Mansfeld-Giese K, Larsen J, Bødker L. 2002. Bacterial populations associated with mycelium of the arbuscular mycorrhizal fungus Glomus intraradices. FEMS Microbiol Ecol. 41(2): 133-140. doi: 10.1111/j.15746941.2002.tb00974.x

Mamatha G, Bagyaraj DJ, Jaganath S. 2002. Inoculation of field-established mulberry and papaya with arbuscular mycorrhizal fungi and a mycorrhiza helper bacterium. Mycorrhiza 12(6): 313-316. doi: 10.1007/s00572-0020200-y.

Olsson PA, Hansson, MC, Burleigh SH. 2006. Effect of P availability on temporal dynamics of carbon allocation and Glomus intraradices high affinity $\mathrm{P}$ transporter gene induction in arbuscular mycorrhiza. Appl Env Microbiol. 72(6): 411-4120. doi: 10.1128/AEM.02154-05.

Orwa C, Mutua A, Kindt R, Jamnadass R, Simons A. 2009. Agroforestree Database : a tree reference and selection guide version 4.0. (http://www.worldagroforestry.org/af/ treedb/). 
Phavaphutanon L, Davies JR FT, Duray SA. 1996. Growth, root alteration, and nutrient uptake of Neem three (Azadirachta indica A. Juss) seedlings in response to vesicular-arbuscular mycorrhizal fungi and phosphorous nutrition. Int Tree Crop J. 9(1): 59-67. doi: 10.1080/01435698.1996.9752960.

Roesti D, Ineichen K, Braissant O, Redecker D, Wiemken A, Aragno M. 2005. Bacteria associated with spores of arbuscular mycorrhizal fungi Glomus geosporum and Glomus constrictum. Applied Environ Microbiol. 71(11): 6673-6679. doi:10.1128/AEM.71.11.

Rotor AV, Delima PC. 2010. Mycorrhizal association, N fertilization and biocide application on the efficacy of bio-N on Corn (Zea mays L.) growth and productivity. E-Int J Sci Res. 2 (3): 267-290.

Selvaraj M, Mosses M. 2011. Efficacy of Melia azedarach on the larvae of three mosquito species Anopheles stephensi, Culex quinquefasciatus, and Aedes aegypti (Diptera: Culicidae). Eur Mosquito Bull. 29: 116-121.

Secilia J, Bagyaraj DJ. 1987. Bacteria and actinomycetes associated with pot cultures of vesiculararbuscular mycorrhizas. Can J Microbiol. 33(12): 1069-1073. doi: $10.1139 / \mathrm{m} 87-187$

Shtark OY, Borisov AY, Zhukov VA, Provorov NA, Tikhonovich IA. 2010. Intimate Associations of Beneficial Soil Microbes with Host Plants. In: Dixon GR and Tilston EL, editors. Soil Microbiology and Sustainable Crop Production. The Netherlands: Springer Science+Business Media B.V. p 119-196. doi: 10.1007/978-90-481-9479-7 5.

Smith SE, Smith FA, Jakobsen I. 2003. Mycorrhizal fungi can dominate phosphate supply to plants irrespective of growth responses. Plant Physiol. 133(1): 16-20.

Theather RM, Wood JP. 1982. Use of Congo red polysacharide interaction in enumeration and characterization of cellulolytic bacteria from the bovine rumen. Appl Environ Microbiol. 43(4) : 777-780.

Yulianti, Siregar IZ, Wijayanto N, Darma IGK T. 2011. Genetic variation of Melia azedarach in community forests of West Java assessed by RAPD. Biodiversitas 12(2): 64-69. 